\title{
INDO-JAPAN RELATIONS: DEEPENING BONHOMIE AND NEW SECURITY EQUILIBRIUM IN THE ASIA-PACIFIC
}

\author{
Sudhir Singh
}

\begin{abstract}
Bilateral relations between India and Japan have become one of the most significant interactions for the future. Though economically important, it is the strengthening of strategic relations which has increasingly assumed greater value since the beginning of the twenty-first century. Economically, East Asia, is one of the most dynamic regions in the world, hence, most major powers are interested in its development. Managing relations with China and dealing with the rising stature of Beijing in the region is a cause of concern for both India and Japan. There are several persistent divergences between Japan and China which at any point of time can create a crisis. There are also serious divergences in the relations between India and China which often poses obstruction to the development of stable relations. Hence, the main objective of both India and Japan is to maintain a balance of power in the region and prevent any one country from becoming too dominant. It is also true for the larger canvass of Asia-Pacific as Asian countries want stronger Indo-Japan relations within a multilateral framework that includes the United States.
\end{abstract}

Keywords: India, Japan, East China Sea, United States, ASEAN, Shinzo Abe, Modi

\section{Introduction}

When Indian Prime Minister (PM), Narendra Modi visited an old Buddhist temple in the city of Kyoto during his August-September 2014 Japan tour, it vindicated the level of soft power synergy between both countries. However Indo-Japan relations have witnessed gamut of ups and downs in the last 67 years. Indo-Japan relations have grown phenomenally since last 15 years. The end of the Cold War radically transformed many bilateral relations and of course Indo-Japan relations fall under that category and proved the Kautilyan notion that foreign policy is shaped by the convergences of interests and constant changes. Rarely before in recent history has Japan gone so much out of its way to welcome a foreign leader as it did when it received Prime Minister Modi. His counterpart, Shinzo Abe, broke protocol in receiving Modi in Kyoto and spending the weekend with him in the same city.

Interestingly, in May 1998, when India denoted a nuclear device, sanctions by important western countries followed. Japan and Australia also imposed gamut of sanctions on India. Today in the second decade of $21^{\text {st }}$ century, the security architecture of Asia-Pacific is changing very rapidly. Indo-Japan relations were cemented in postPokhran scenario. Two millennia ago the seminal Indian strategic thinker, Kautilya stated that foreign policy is the convergences of national interests and other kinds of convergences barely matter. India and Japan share many things but due to divergences of ideology they were almost hostile to each other during the Cold War era. Nehru's obsession with idealism could be blamed for the non-response from Japan for better relations with India. The balance of power game during the Cold War era further strengthened the rift. However, relations radically changed after the end of the Cold War. In the $21^{\text {st }}$ century Japan is being confronted with many contemporary problems. 
Many of these problems are common to both countries. This article is intended to analyze these issues.

\section{Historical Background}

A unique paradox has defined India-Japan ties. On one hand, there is absence of a major dispute; on the other, the richness in relations has not been fully exploited for many years due to gamut of factors. Looking back in time, the post-Second World War period saw both countries share intellectual discourse and a common vision of Pan Asianism. Japan held a special place for supporting the members of the Indian revolutionary freedom struggle. Thereafter, the saga of India-Japan relations was that of benign neglect for much of the Cold War period.

Rich cultural, literary and religious linkages coalesce to provide a positive bedrock to India-Japan relations. Historically, India-Japan relations have existed for more than a thousand years. It is said that Japan first came into contact with India during the reign of Emperor Kimmei (539-571 A.D.). ${ }^{1}$

Buddhism was the first common link between both sides, although it did not really find its way directly from Japan to India. Korea was instrumental in introducing Japan to the Buddhist philosophy. Buddhism became the state religion of Japan under the rule of Prince Umayado (593-622 A.D.). ${ }^{2}$ The Buddhists promoted art, culture and philanthropy, gradually spreading its roots to many parts of the country, even as it branched out into several cults and sects like Tendai and Shingou. ${ }^{3}$ The influence was deep and widespread. According to Haijima Nakamura, "Without Indian influence, Japanese culture would not be what it is today." 4

These Japanese links with Buddhism in India continue even today with a number of Japanese visitors travelling to cities like Bodh Gaya. The Japanese initiative (along with Singapore) behind the revival of the Nalanda University in the Indian city of Bihar as a prominent seat of learning also has its roots and connections with Buddhism. Historically, Nalanda was a Buddhist seat of learning from the fifth or sixth century CE to $1197 \mathrm{CE}$ and continued to receive support and patronage from a number of emperors who were Buddhist devotees.

The second vital connection was a result of a common interest in advancing PanAsianism. During the period of the Indian Renaissance (1881-1905), India was keen to initiate the spirit of Asian oneness. The trend towards Asian-ness identifying with and aligning with the rest continued as intellectuals like Swami Vivekananda travelled to many parts of the region. Swami Vivekananda visited Japan in 1893 and was impressed by Japanese nationalism. ${ }^{5}$

1 David Brewster, "The India-Japan Security Relationship: An Enduring Security Partnership?", Asian Security, Vol. 6, No. 2, 2010, pp. 95-120; Bill Emmott, Rivals: How the Power Struggle between China, India and Japan Will Shape Our Next Decade, London: Allen Lane, 2008.

2 Kalidas Nag, "Greater India”, Greater India Society Bulletin, No. 1, November 1926, p 32.

3 Kalidas Nag, pp 33-34.

4 Haijima Nakamura, Japan and Indian Asia, Calcutta, 1961, p 1.

5 Birendra Prasad, Indian Nationalism and Asia, 1900-1947, Delhi: B. R. Publishing Corporation, 1979, p 31. 
Despite Japan's aloofness with the rest of the world, the connectivity between India and Japan flourished with the fast-growing Japanese spinning industry, which found India as a source of raw cotton. India also became a destination for finished Japanese goods. Perhaps the most significant bilateral contact was that of Indian industrialist J. N. Tata who visited Japan in 1893 and set up an office there. The initiation of trade ties led to the establishment of a Japanese consulate office in Bombay and consulate general office in Calcutta. An Indo-Japanese Trade convention was also signed in 1894 which marked the beginning of "opening of regular ocean transport" between the two sides. ${ }^{6}$

Japanese calls for an Asian identity incorporating countries like Persia, India, China and Japan emerged during the Russo-Japanese war in 1904-1905. Following its victory in the war with Russia in 1905, Japan came to be perceived as a role model in combating colonialism, while its own negative imperial dominance was ignored. In India, there was an obvious and vocal admiration of the Japanese success. In her address to the Indian National Congress in 1917, Annie Besant spoke about the Japanese victory. Indian leaders like Gandhi, Nehru, Gopal Krishna Gokhale and Bal Gangadhar Tilak were all unanimous in their jubilation over the Japanese victory. The Japanese responded positively to Indian enthusiasm. Not surprisingly, the Speaker of the Japanese House of Peers observed that

It was the sacred duty of Japan as the leading Asiatic state to stretch a helping hand ... to India, who is capable of civilization, and freeing them from European yoke. ${ }^{\text {? }}$

The Congress party decided to follow the swadeshi system of boycotting foreign goods. Japanese goods however, were excluded from the banned category. In fact, a prominent Indian newspaper Kesari clearly called on citizens to choose Japanese goods over other foreign manufactured ones. ${ }^{8}$ Any study of India-Japan relations during this period would thus be incomplete without a brief discussion of how prominent Indian revolutionaries like Rash Bihari Bose and Subhash Chandra Bose developed intimate links with Japan. R. B. Bose who came to be known as the "Bose of Nakamuraya" not only took political asylum in Japan, married a native woman, but also spent his entire life in the country as a Japanese citizen (from 1924) till his death in January 1945. ${ }^{9}$

The noted Japanese historian, nationalist and ardent supporter of Indian independence, Shumei Okawa, wrote a book entitled The Current Status and the Origin of the People's Movement in India in 1916, in which he warned the Japanese that by trusting the British they were making a grave mistake and endangering themselves to incurring the wrath of 300 million Indians. ${ }^{10}$ There was tremendous public contempt for the British government which ordered the deportation of Bose and a few other nationalists from Japan. Japanese groups like the Genyosha and Kokuryukai began to connect with the idea

6 T. R. Sareen, "India and Japan in Historical Perspective", Lecture Series on Japan, Issue No. 4, New Delhi: The Japan Foundation, January 2007, pp 10-11.

7 T. R. Sareen, $\mathrm{p} 15$.

8 Birendra Prasad, $\mathrm{p} 31$.

9 Takeshi Nakajima, Bose of Nakamuraya: An Indian Revolutionary in Japan, Translated from Japanese by Prem Motwani, New York: Promilla and Co. Publishers, Bibliophile South Asia, 2005.

10 Takeshi Nakajima, p 124. 
of the Indian freedom struggle movement (despite having ideological differences over the means) as part of their larger aim to work towards the liberation of Asia. ${ }^{11}$

R. B. Bose's legacy of revolutionary streak in seeking independence for India in association with the Japanese was in many ways carried forward by another legendry Bose-Subhash Chandra Bose, who was fast emerging on the horizon of the Indian freedom struggle. S. C. Bose came to Tokyo in 1943 via Germany and met R. B. Bose. He had made it clear that he would not mind working with British enemy states - Japan and Germany in his struggle for independence. Subhash Chandra Bose met Prime Minister Tojo who seemed to be impressed with Bose's intelligence. According to some, the Indian National Army (INA) had been "encouraged" by the Japanese in the hope that it would lead to a Japanese invasion of India. ${ }^{12}$ Bose formed a Japanese-approved and recognized independent "Provisional Government of (Azad Hind) Free India" based in Thailand. In 1943, Bose attended the Greater East Asia Conference in Tokyo. Japan also captured the Andaman and Nicobar Islands and handed them over to Bose's provisional government as a mark of recognition of the free India movement. The INA then, under the leadership of S. C. Bose decided to enter India with the Japanese Army. Following some initial discomfort over the inclusion of Indian soldiers in its assault on Indian borders, the Japanese conceded. The INA attacked and took over the British post at Mowdok in India. The Japanese started to feel the heat of a British counter-offensive. The INA reached and captured Kohima (Assam) and their counterpart Japanese forces tried in vain to gain control over Imphal. The combined Indian and Japanese forces finally buckled under a British attack and had to retreat in 1944-1945.

On the cultural and literary front, the legendary friendship between Okakura Tenshin and Indian poet Rabindranath Tagore during this period is well known, which cemented ties and even today remains an inspiration for both countries. Okakura first visited Kolkata in 1902 with the aim of inviting Swami Vivekananda for the Parliament of Eastern Religions to be held in Japan. He also utilized this visit to study Indian architecture and arts as well as also assist India in its struggle for freedom through inspiring young Indians to aim for complete independence..$^{13}$ Tagore also visited Japan three times and became a key cultural ambassador of India in Japan. Further, Japan's wartime Prime Minister Tojo referred to India in his speech to the Japanese Diet in 1942 after the defeat of Singapore,

This is the best opportunity for India to rid itself of the despotic policy of oppression by the British and participate in building the Greater East Asia Co-prosperity Sphere. The Japanese Empire hopes to restore India to its original status, whereby the nation belongs to Indians, and we will provide all help to the patriotic efforts of the Indian people. It would be really unfortunate if India does not return to its history and traditions; awaken to her mission. ${ }^{14}$

11 Takeshi Nakajima, p117.

12 R.B. Smith, "The Tokyo Conference and the Greater East Asia Perspective, 1943", in Chad J. Mitcham (Ed.), Changing Visions of East Asia 1943-93: Transformations and Continuities, London: Routledge, 2007, p. 24.

13 Kazuo Azuma, "Meeting of Okakura Tenshin and Rabindranath Tagore as a Great Opportunity", from Path from India, Path from Japan: Lecture Series on Japan-India Relations, Compiled by Sengaku Maeda, New Delhi: Northern Book Centre, 2008, pp127-140.

14 R.B. Smith, p 256. 
But with Japan's militarization and imperialist lashing-out in the 1930s, relations between India and Japan began to deteriorate. Japan's advancement into China - the Manchurian Incident, its actions in Korea (1910-1911) eroded the positivity which defined and underlined bilateral relations. Nehru was critical of Japan and openly critiqued Tokyo for its Westernization, expansionism and imperialistic tendencies. He noted, "Japan not only followed Europe in industrial methods, but also in imperialistic aggression." 15 Nehru, who tilted towards China, avoided Japan even after independence.

When India gained independence, India took on the yoke of anti-colonialism and anti-imperialism. Nehru joined the Bandung Conference which was held in 1955. This was Nehru's "honeymoon" period with China. The Cold War further cast its shadow on Indo- Japan ties. The chill in relations was evident after Japan became an ally of the United States, while India chose to espouse the path of non-alignment, but with a definitive tilt towards the Soviet Union.

\section{The Cold War Era}

The end of the Cold War has witnessed a new realization of Indian realism in foreign policy. The launching of "Look East Policy" in 1992 was an important step in this direction as far as Asian balance of power is concerned. In the aftermath of its "LookEast Policy", Indian economic links with ASEAN in general and Japan in particular has seen a constant improvement. Economic relations with South East Asian countries have emerged as a major pillar. With the implementation of India-ASEAN Free Trade Agreement in Goods, trade with ASEAN has grown by $37 \%$ to a level of almost $\$ 80$ billion by the end of 2012. India -Japan bilateral trade was 17.7 \$ billion between 2010 and 2011. Bilateral trade reached US $\$ 16$ billion between January-November 2012 and increase rapidly the following year due to inherent nature of growing bonhomie. ${ }^{16}$

The divergence of opinions from analysts since the end of the Cold War regarding Asia being an important player in the $21^{\text {st }}$ century has been well documented. With the end of the Cold War, new thoughts flourished by the formulators of foreign policy that both the World and the Asian system must be multi-polar. There exists a significant divergence of interests between India and China, as to the type of international system that should develop in the post - Cold War era. India believes that the world must be multi-lateral. China believes that the Asian balance of power must be uni-polar, headed by Beijing. Japan shares similar perceptions with India. Therefore since the end of the Cold War, bilateral relationship between India and Japan has been deepening due to growing convergences. Among others, both countries share common perceptions of issues like the G-4 campaign for enlargement of United Nations Security Council, cooperation to guard against China's hegemonic role in Asia, joint strategies to handle maritime and space security issues. This is vindicated with the frequent high level

15 Jawaharlal Nehru, Glimpses of World History, Delhi: Oxford University Press, 1989 [1933-1934], p 457, as cited in Christopher Jaffrelot, "India's Look East Policy: An Asianist Strategy in Perspective", India Review, Vol.2, No. 2, April 2003, p 39.

16 Annual Report, 2012-2013, Ministry of External Affairs, Government of India, New Delhi, 2013, pp 9-12. 
meetings between the leaders of both countries. ${ }^{17}$ For example, during Prime Minister Koijumi's visit to India in 2005, an eight fold initiative was agreed. It included the following points ${ }^{18}$

- Enhancing dialogue and exchanges, including high-level strategic dialogue

- Comprehensive economic engagement

- Enhancing security dialogue and cooperation

- $\quad$ Science and technology initiatives

- Cultural and academic initiatives

- Cooperation in ushering a new Asian era

- Cooperation in the United Nations (UN), specifically for Security Council Reforms

- Cooperation in responding to global challenges and opportunities

In particular, Indo-Japan relationship has grown rapidly in the last decade. Due to inherent geo-political, economic and strategic dimensions, this bilateral relationship is all set to reformulate a new Asian balance of power based on multipolarity. No concept in the realm of international politics has been discussed more often than balance of power. It has been defined in so many ways, despite the diversity of narratives, it has remained an ambiguous idea. Used objectivity or descriptively, the term indicates the relative distribution of power among states into equal or unequal shares. Traditionally, it refers to a state of affairs in which no one state dominates over others. Prescriptively, it refers to a policy of promoting some sort of power equilibrium on the assumption that unbalanced power is dangerous. Prudent states that are at a disadvantage in the balance of power will (or at least should) form an alliance against a potentially hegemonic state or take other measures to enhance their ability to restrain a possible aggressor. Also, one state may opt for a self conscious balancing role, changing sides if necessary to preserve equilibrium. A balance of power policy requires that a state moderate its independent quest for power, since too much power in one state may bring out selfdefeating reactions of fear and hostility from other states. ${ }^{19}$ China, Japan, India and Vietnam are involved in the balance of power struggle within Asia. Other countries do not want China's supremacy. He3nce, the bonhomie is deepening in an excellent manner in the last one decade and the relationship is set to grow in the foreseeable future. In the year 2012, China's actions has exposed that it could use force to annex islands in East China Sea which are under Japanese rule for many decades. In many areas of China including Hong Kong, protests against Japan had been organized which demanded

17 Two Indian Presidents visited Japan - Rajendra Prasad in 1958, and R. Venkataraman in 1990. The Japanese Emperor visited India in December 2013. However, the Japanese Crown Prince visited India twice in 1960 and 1992. Nine Japanese Prime Ministers have visited India - Kishi in 1957, Ikeda in 1961, Nakasone in 1984, Kaifu in 1990, Miyazawa in 1992, Mori in 2000, Koijumi in 2005, Abe in 2005 and Hatoyama in 2009. Only eight such reciprocal visits were from India -. Nehru in 1957, Indira Gandhi in 1969, Rajiv Gandhi in 1985, P.V. Narasimha Rao in 1992, A.B.Vajpayee in 2001, Manmohan Singh in 2006, 2008,2010 and 2013. Refer to the MEA Report on India-Japan Relations at http;//meaindia.nic.in/meaxpsite/foriegnrelation/ japan.pdf.

18 Ministry of External Affairs Annual Report 2005-2006, Government of India, New Delhi, 2006, $\mathrm{p} 34$.

19 Grifiths, Martin \& Terry O Callaghan, Key Concepts in International Relations, London: Routledge, 2004, p 2. 
the capture of Japanese ruled islands in the East China Sea. Including United States, India insists on an amicable resolution of disputes and adherence with international law by all concerned parties. In the South China Sea dispute, China has shown it does not abide relevant international laws. South China Sea is a serious flashpoint among ASEAN disputant countries and China. Beside Vietnam, Indonesia, Malaysia, the Philippines and Brunei are also confronting China over the overlapping claims in the South China Sea. It has emerged as potential global flashpoints. The Nation in Bangkok warned in an editorial that,

If the current tension continues in South China Sea, especially between the Philippines and China, it could lead to an all-out war. This is not an alarmist's warning but a real concern. With poisonous rhetoric and growing tension, there is a possibility that conflicting parties would cross the line. This could be a result of miscalculation. ${ }^{20}$

Because of border disputes, India is also apprehensive about Chinese strategies therefore it has strengthened its bilateral relationship with Japan in a huge way. These events vindicate that balance of power theory is working well in Asia. The currant balance of power will sustain due to Chinese reluctance to accommodate the aspirations of other countries.

The new security architecture within Asia is emerging. In this process many traditional players will lose some power, while some new players will acquire new acumen in this emerging power game. Long back during the Peloponnesian War, Thucydides (c. 471-400 BC), the great Athenian historian, regarded in the west as the founder of international relations theory, identified the root cause of war between Sparta and Athens as the struggle for power. He argued,

what made war inevitable was the growth of Athenian power and the fear which this caused in Sparta. In the first stage of the war, Sparta, the predominant power, decided to wage war against Athens; while in the second stage, Athens, the rising power, was determined to conquer Sparta. ${ }^{21}$

Of course, time and context has changed but the real struggle of power still holds the same dimension. The new balance of power in Asia is all set to reshape existing security architecture. However the theory of balance of power according to its proponents has come into being with the theory of Prisoner's Dilemma. Balance of power has been one of the most debated concepts in international relations. Balance of power is a kind of compromise among states that finds its order preferable to absolute chaos, even though it is a system that favors the stronger and more prosperous states at the expenses weakerones. Great powers play the dominant role in the balance of power game because of their preponderant military force and their control of key technologies. ${ }^{22}$ The Cold War era is a classic example of balance of power between the United States and the Soviet Union. In the post Cold War era, the prevalence of the possible anarchic international environment has created a fear psychosis. Military build-ups and its competition by rival powers have left every harbinger of the international system insecure therefore

20 'Temperatures Rising in the South China Sea,' The Nation, 28 May 2012.

21 Qing Simei, From Allies to Enemies ; Vision of Identity, and US- China Diplomacy,1945-1960,

Harvard University Press, Cambridge, 2007, p 297.

22 Griffiths, Martin \& Terry O Callaghan, p 13. 
all countries are trapped in a dilemma. This kind of phenomenon is called the Security Dilemma. $^{23}$

Right from Kishore Madhubani to many pundits of international relations are saying that Asia is emerging but the billion dollar question is why Asian powers are not cooperating. By not cooperating, they are negating the utopian idea of Nehru that collaboration among neighbouring countries is way better than the European international relations dreamt by Wilsonian practitioners of foreign policy. One can argue that the lust for balance of power and existing historical baggage are forceful factors that increase Cold War aloofness within Asia and thus negates the utopian ideas of Nehru's robust Asian cooperation. China, India, Japan, South Korea, Indonesia, Iran and Vietnam are some of the important Asian powers. The changing power configuration is anti-thesis to Nehru's hypothesis. Asia seems to follow the European model of conflict. Nonetheless, the post Second World War Europe has emerged as a beacon of cooperation and won the Nobel Prize for peace in 2011/12 and must be emulated by other regional groupings. Major Asian countries are not cooperating because there is a divergence of interests. China wants its unipolar dominance over Asia but supports multi-polarity at the global level. India, Japan, South Korea, Indonesia, Iran and Vietnam want both Asia and the world to be multilateral. Convergences of interests between India and Japan will become significant in the $21^{\text {st }}$ century. It is also an open secret that they Indo-Japan relations were strained during the Cold War. The 1998 Pokhran bomb test which took the world by surprise saw Japan react negatively. It suspended and froze all political exchanges and even economic assistance for nearly three years. However, a ties were revived in August 2000, when the then Japanese Prime Minister Yoshiro Mori paid a five-day visit to India. Mori and the then Indian Prime Minister Atal Bihari Vajpayee called for a "global partnership." From then on, relations have witnessed steady progress. During the visit of the Indian Prime Minister Manmohan Singh to Tokyo in 2006 during the first administration of Shinzo Abe, the two Prime Ministers decided to advance bilateral relations through a "strategic partnership."

In the last few years, China-Japan and China-India divergences have been increasing. In July 2012, Japan recalled its envoy from Beijing over a disputed territory in the East China Sea. ${ }^{24}$ It is a coincidence that in July 2012 also, China refused to issue Visa to an athlete originating from Arunachal Pradesh, which China perceives as its own territory. ${ }^{25}$ Despite 17 rounds of high voltage bilateral dialogue till September 2014, there was not even an iota of progress over thorny boundary disputes between India and China. Other divergences like water flow from Tibet, trade deficit and many other issues are contributing to trust deficit. These prevailing situations have brought India and Japan closer. Chinese officials are worried that this growing relationship is meant to contain and counter Beijing. According to two leading foreign policy experts from the China Institute of International Studies " India's border dispute with China have yet to be resolved, therefore it views a stronger relationship with Japan as a way to counter balance China's growing influence in the Asia-Pacific region." 26

23 Herz, John, H, “Idealist Internationalism and Security Dilemma," World Politics, Vol. 2, 1950, pp 157-158.

24 'Japan Recalls China Envoy over Territory Dispute,' The Hindu, New Delhi, July 16, 2012.

25 Dasgupta, Saibal, 'MEA fumes as sports Minister Team Ignores China Snub,' The Times of India, 15 July 2012.

26 Dasgupta, Saibal, 'China Sees Growing India-Japan Ties as Move to Counter it,' Times of India, September 20, 2012. 
As China's dispute with Japan escalates over islands in the East China Sea, Beijing seems worried that India will throw its weight in favor of Tokyo. Chinese experts believe that India and Japan share much more strategic interests and common ground in regards to China. For the first time in contemporary history, Chinese experts have come to accept that India is working on the reciprocation of Chinese policy of encircling India within South Asia and therefore New Delhi is deepening its relationships with all estranged neighbours of China. ${ }^{27}$

India-Japan relations have undergone a significant and qualitative shift in recent years. The government and Japanese citizens were appreciative of India's sympathetic response and assistance to the victims of the earthquake and tsunami that struck the country in March, 2011, and the ensuing nuclear crisis. India sent variety of relief materials. The Japanese Prime Minister, Mr. Yoshihiko Noda, came to India on a State visit on 27-28 December, 2011, for the Annual Summit between the two countries. A Joint Statement titled 'Vision for the Enhancement of India-Japan Strategic and Global Partnership upon entering the year of the $60^{\text {th }}$ Anniversary of the Establishment of Diplomatic Relations was signed by the two Prime Ministers during the Annual Summit. During the visit, the Japanese side renewed its commitment to flagship infrastructure projects like the Delhi-Mumbai Industrial Corridor Project and the Dedicated Freight Corridor West Project, and expressed support for the new Chennai- Bengaluru Industrial Corridor Project. Further, trade figures are expected to increase as a result of the IndiaJapan Comprehensive Economic Partnership Agreement (CEPA), which came into force on 1 August, 2011. For the eighth consecutive year, India in 2011 continued to be the largest recipient of Japanese ODA.

\section{United States as a Factor}

President George W. Bush who ruled the US between 2001 and 2008 had intended to provide space for India to grow in Asia. However, the foundation was cemented in the second tenure of President Clinton. In 2000, Indian Prime Minister Atal Bihari Vajpayee clarified in Washington that the United States and India were natural allies. During President Bush's era bilateral relationship further expanded putting China in a situation which is known as 'Prisoner's Dilemma' in international politics. China was of course one of the main reason as to why President Bush reached out to India. Robert Blackwill, the US Ambassador to India who was an important architect of the Bush era's India policy articulated that President George W. Bush, while not trying to contain China, saw a democratic India as a key factor in balancing the rise of Chinese power. Further, Blackwill argued that the China factor forced Congress to accept the Civil Nuclear Agreement with India." ${ }^{28}$ With India-US relations strong, China remains sensitive to a strong India-US relationship. China is fearful that the closeness is bound to weaken Beijing's her position. Hence, China wants to establish a new balance of power in Asia based on multipolarity.

Japan-United States bonhomie is one of the oldest in Asia since the end of the Second World War due to the emergence of the Cold War. The post Cold War Asian

27 Times of India, September 20, 2012.

28 Robert Blackwill, "The Future of US-India Relations, Address to the Confederation of Indian Industry, New Delhi," May 5, 2009, available at <http:/ / www.stratpost.com/ the-future-of-us-indiarelations- blackwill> accessed on 9 January, 2011. 
architecture of power has further consolidated U.S-Japan relationship. In recent years, China has been assertive and negating the international law rights of neighbouring countries particularly in the South China and East China Seas, claiming the waters as its own. Unlike its Southeast Asian neighbours, Japan has challenged China. Further, the US has extended its support to Japan and reaffirmed that International Law must be followed. This has further put strain in bilateral relations of Japan and China and in contrast has strengthened US-Japan relations. As this situation converges with Indian interests, since the last decade, Indo-Japan relations has emerged as a vital bilateral relationship in Asia. This has forced Chinese policy formulators to admit the importance of cooperation while understanding other sensitivities. It is vindicated by the editorial of June 2009 in the Global Times, supposedly the mouth piece of the Chinese government, that

India has long held contradictory views on China. Another big Asian country, India is frustrated that China's rise has captured much of the world's attention. Proud of its 'advanced political system', India feels superior to China. However, it faces a disappointing domestic situation which is unstable compared with China's. India likes to brag about its sustainable development, but worries that it is being left behind by China. China is seen in India as both a potential threat and a competitor to surpass. But India can't actually compete with China in a number of areas, like international influence, overall national power and economic scale. India has apparently not realized this. Indian politicians these days seem to think their country would be doing China a huge favor simply by not joining the 'ring around China' established by the United States and Japan. India's growing power would have a significant impact on the balance in this equation, which has led India to think that fear and gratitude for its restraint will cause China to defer to it on territorial disputes. But this is wishful thinking, as China won't make any compromises in its border dispute with India. And while China wishes to coexist peacefully with India, this desire isn't born out of fear..$^{29}$

\section{Post Cold War Scenarios \& the China Factor}

China's concerns about expanding Indo-US defense cooperation acquired an extra edge when it saw Tokyo joining Washington in the security outreach to New Delhi. Unlike much of East Asia, India carries no baggage about Japan's history or a grudge against its nationalism. The implementation of the Indo-US nuclear agreement and the likely change in Japan's policy on sensitive exports to India could open doors for a very rewarding high technology partnership between Tokyo and New Delhi. India and Japan have also agreed to expand their current defense cooperation which is focused on securing the sea-lanes in the Indian Ocean, immensely vital for Japanese access to energy and raw materials. ${ }^{30}$ Since the US still remains the biggest balancer of Asia therefore deepening of US-India relationship has supported a stronger Japan-India relationship.

The Chinese are reserved in admitting India into any East Asian security or economic platforms. Nonetheless, India has been admitted into the East Asia Summit despite Chinese protest and this has emboldened Japan. The prevailing Sino-Japan trust deficit over a gamut of issues has raised ample opportunities for a deepening India-

29 'India's Unwise Military Moves,' Global Times, 11 June 2009, available at http:/ /opinion. globaltimes.cn/editor-picks/2009-06/436167.html, accessed on 8 January, 2011.

30 Gurpreet S. Khurana, "Security of Sea Lines: Prospects for India-Japan Cooperation", Strategic Analysis, Vol.31, No.1, January 2007. 
Japan relationship. Prime Minister Abe has vowed for better bilateral. Russia has also felt the heat of a resurgent China particularly in its Far Eastern region, which is sparsely populated but rich in natural resources with a huge landmass. The Chinese have an eye on this far flung Russian region due to its geographical proximity and natural resources. Russia's relations with India have improved as a result of increasing Chinese aggressiveness. In case of the East China Sea dispute between China and Japan, China refuses to obey the 1982 United Nations Laws of the Sea and other relevant international laws. This has propelled the ongoing tension between both rivals. Needless to say, an increasing Russian role in the Asia-Pacific is intended to contain China and of course that is the point where convergences of interests compels India, Vietnam, ASEAN, Australia and the United States to extend their support to to Indian interests. ${ }^{31}$

India has given unprecedented importance to Asian balance of power within the contours of its foreign policy. The core of Indian foreign policy is now the "Look East Policy (LEP)." It was articulated by Prime Minister Atal Bihari Vajpayee during his 2002 visit to Singapore. Looking beyond, the LEP was not limited to Southeast Asia. Vajpayee declared that geography and politics make India an important partner of the Asia-Pacific community and that "it does not require formal membership of any regional organization for its recognition or sustenance". ${ }^{32}$

In recent years, India has shed it Nehruvian shyness and has expressed deep interest in the affairs of all issues of Asia-Pacific. It could be said that India has now initiated the third phase of the LEP with special focus of security issues besides other issues of importance. The third phase of the LEP was marked by India's public claim of its engagement in affairs in East Asia and Asia-Pacific at large. The move began with the speech from Indian Defence Minister A.K. Antony in the first ASEAN Defence Ministers' Meetings Plus (ADMM) in October 2010 in Hanoi. Never before had an Indian official publicly supported and committed to secure the freedom and safety of navigation in Asia-Pacific region. It was a much needed bold step in the changing contours of the architecture of balance of power in Asia-Pacific. Further, the US is also wants India to enhance its presence in the region. A.K.Antony observed that it is in the common interest of nations to keep sea lanes secure and free for navigation, trade and energy supplies. He further reiterated that through the Regional Cooperation Agreement on Combating Piracy and Armed Robbery against Ships in Asia (ReCAAP) and the Malacca Straits mechanisms, India is partnering with other countries in the region to improve the safety of navigation in the region. ${ }^{33}$

The growing uncertainty between Sino-Japan relationships has given a new twist to Japan-India relationship. India and Japan are part of many bilateral and multilateral military exercises with like-minded countries. Defense and non - security threat cooperation like disaster management is also going on. Both countries have maintained high level summits and trade is also gradually catching up. China claims

31 Dr. Indrani Talukdar, A ‘Reset' in Russia and Japan Relationship? Indian Council of World Affairs, 3 March, 2014, p 1.

32 Atal Bihari Vajpayee, "India's Perspectives on ASEAN and the Asia-Pacific Region", 21st Singapore Lecture, Institute of Southeast Asian Studies, 9 April 2002, available at <http:/ / www.iseas.edu.sg/ vajpayee.pdf> accessed on 9 January, 2011.

33 "India Calls for Cooperative Approach to Ensure Security of Sea Lanes," Asian Military Review, October 12, 2010 <http:/ / www.asianmilitaryreview.com/News/index.php?hNewsId=1359> accessed on 4 anuary , 2013. 
the East China Sea Islands which is under Japanese control for many decades. China is willing to transform its new strength to dominate the region which is resisted by Japan. India has not only supported Japan in these disputes but called upon the international community to ensure the compliance of international laws of navigation and other rights. This conflict has sowed the seed of trust deficit between Japan and China. Though Japanese companies have invested in China in a massive scale, the current situation has compelled Japan to rethink the relocation of its investment to India. Already Japan has increased the pace of investment into India but in the prevailing situation it is bound to further accelerate trade links. Hence, India desperately needs to facilitate these potential investments through immediate clearance and expansion of infrastructure. PM Modi's August-September 2014 Japan tour resulted in Japan pledging \$35 billion investment in India. ${ }^{34}$

Prime Minister (PM) Shinzo Abe wants better relations with India. In the fast changing geopolitics of East Asia and Chinese assertiveness will further cement IndiaJapan bilateral relations. PM Abe has visited many important ASEAN countries. He has given utmost importance to Vietnam which is in conflict with China for decades. Though ASEAN's economic relations with China is worth $\$ 350$ billion, trust deficit still prevails. ASEAN countries want Japan and India to unite indealing with Chia based on the compliance of international law to resolve thorny issues including the South China Sea dispute. In 2010, Beijing announced that South China Sea area which is bigger than the Mediterranean is a core interest of its policies comparable to Tibet and Taiwan. ${ }^{35}$

Likewise on November 23, 2013, Beijing announced that an Air Defense Identification Zone (ADIZ) which overlaps with air spaces controlled byntrolled by both South Korea and Japan in order to control the disputed islands in the East Sea. The announcement was alarming, particularly because it included a warning that

China's armed forces will adopt defensive emergency measures to respond to aircraft that do not cooperate in the identification or refuse to follow the instructions." ${ }^{\prime 36}$ The warning was tested at once by military aircraft from the United States, South Korea, and Japan. When China failed to take immediate action to enforce this, however tensions diminished. ${ }^{37}$ Then confrontation in international waters took place, on December 5, 2013, between the Chinese Liaoning aircraft carrier battle group and the U.S Ticonderoga class guided missile cruiser, U.S.S Cowpens. From which the Cowpens withdraw. ${ }^{38}$

The strength of the relations was reflected by PM Abe being the chief guest of the 2014 Republic Day and the Japanese emperor visiting India in December 2013. Although trade and investment has remained low between both of the countries in comparison with China but at the strategic level both are availing excellent relationship. Indian

34 Brahma Chenllancy, Asian Juggernaut: The Rise of China , India and Japan, Harper Collins, New Delhi, 2006.

35 Li Hongmei, " Unwise to Elevate South China Sea to Core Interest? People's Daily Online, August 27, 2010, < http;//English.peopledaily.com.cn/90002/96417/7119874.html> 6 January, 2014.

$36<$ <ttp;//news.xinhuanet.com/English/china/2013-11/23/c 132911634.htm>6 January, 2014.

$37<$ http;//breakingdefence.com/2013/11/chinas-new-defence-zone-drives-korea-japan- $\mathrm{t}>6$ January, 2014.

$38<$ http;//thediplomat.com/2013/12/how-the-us-lost-the-south-china-sea-standoff/> 6 January, 2014. 
Prime Minister, Modi visited Japan in August-September 2014. It was his maiden visit outside from the sub-continent after coming into power with a full majority in May 2014. During his visit, Japanese PM Shinzo Abe broke all protocols and received Modi right at the airport. Given the lack of trust with China, Japan and India want multipolarity to be the basis of Asian international relations. India-Japan political relations are bound to strengthen as well as trade and investment will grow simultaneously. Such a strategic relationship has the potential to reshape a new equilibrium in the Asia-Pacific region.

\section{Concluding Remarks}

Globalization has certainly reduced tensions between countries through trade links. China and Japan have a strong trade relationship. Nonetheless, the soft power of globalization is not faring well. Japanese Prime Minister Shinzo Abe caused a stir in Davos, Switzerland, when he noted in January 2014 that Britain and Germany went to World War in 1914 even though they had close economic ties similar to China and Japan have these days. ${ }^{39}$

China has immense rivalries over South China Sea with ASEAN countries and over the East China Sea with Japan. With growing economic might, China aims to convert it into military might. Japan opposes the militarization of China. Since, India and Japan have converging interests, it is likely sustain bilateral relations in the foreseeable future. As security analyst Raja Mohan stated

For nearly four decades, Japan and China have had closer relations with each other than India. As they clash today, both attach considerable value to their relationship with India, which has the potential to alter larger Asian context. Rising China's interest is essentially a negative one, to keep the relationship with India tranquil as its confronts Japan in the east. Tokyo's interest is positive, as it seeks to build a strong strategic partnership with Delhi to balance on increasingly assertive Beijing. ${ }^{40}$

Given the Kautilyan notion that there are no permanent friends or foes in foreign policy and only convergences of interests, Indo -Japan relations are bound to reach new heights. Deepening Indo-Japan relations has the immense potential not only to sustain multipolarity in Asia but also to propel Indian influence in the larger canvass of the Asia-Pacific region. According to Goldman Sachs, the Indian economy will quadruple in size from 2007 to 2020, and will surpass the size of the US economy to be second only to China's by 2043. ${ }^{41}$ These projections are not difficult to achieve but needs a credible strategy. India has already started to improve relations with ASEAN and Japan. Unlike China, in the Asia Pacific Region, India is not viewed as an expansionist state.

With the business minded NDA-2 government taking over New Delhi through the leadership of Modi in 2014, Modi's close rapport with PM Abe, and the trust deficit between Japan and China, and both countries being important stakeholders of the Asian balance of power paradigm, the relationship is bound to leap forward and eventually

39 Keith Bradsher, 'Philippine Leader Sounds Alarm on China,' New York Times, New York, 5 February, 2014.

40 C. Raja Mohan, 'Retooling for a new Asia,' The Indian Express, New Delhi, 23January, 2014.

41 BRICs and Beyond (New York: Goldman Sachs Economics Department, November 2007). 
determine the shape of Asian security architecture. As an editorial in Yomiuri Shimbun (Japan's largest circulating newspaper) noted,

\section{India is an extremely important partner with which Japan can shape a new international order} in East Asia because the two countries share common values of freedom and democracy. ${ }^{42}$

Growing Indo-U.S relations after the end of the Cold War has further put the Chinese in a fix. Compared to the Bush era, during President Barrack Obama's, relations have not been perfect but it is improving. The warmth President Obama showed towards PM Modi's US visit in September 2014 is self-explanatory. China has been extremely envious of cooperation between democracies. Moreover, majority of ASEAN countries, the US, Japan, Australia and India have all adopted democracy as a way of governance. The Global Times, the mouth piece of Chinese regime expressed frustration in December 2010,

The title of "the biggest democratic nation" looks like a glass of red wine enjoyed together by India and the West. But it doesn't generate anything substantial that is of India's national interests. With a huge population and much work left to be done in developing the economy, perhaps India won't get too drunk to act superior in front of China, because such superiority will delight India much less than it delights the West.' See who wins the Dragon-elephant contention. ${ }^{43}$

Despite Chinese overt and covert opposition, Indian acceptability is growing in Asia. Edward Luce, the Washington bureau chief and former South Asia bureau chief for the Financial Times is of the opinion that India's emergence as a strong economic and military player is likely to strengthen global and regional stability. On a geopolitical level, India and Japan can both be considered potential rivals to Chinese primacy in the broader region. In an effort to forestall competition from its neighbors, China has attempted to prevent both countries from gaining equal international status by opposing the expansion of the United Nations Security Council and also by resisting legitimization of India's nuclear arsenal. Such clumsy efforts have only driven New Delhi and Tokyo closer together. The Indian expert Brahma Chellency notes that Japan has already assisted China through larger-scale aid, investment and technology transfer over three decades and now is ready to concentrate on India become an economic powerhouse similar to China. ${ }^{44}$

In sum, convergences are increasing between India and Japan. PM Modi's August-September 2014 visit to Japan has paved the way for deeper strategic and economic relationship between both countries. Both democracies have political stability and domestic support which will aid in bilateral relations and reshape the existing equilibrium of power balance in the Asia-Pacific region. The power balance will certainly establish a new order based on peace, stability, economic development and the compliance of international laws.

42 'Japan-India Partnership Vital in East Asia,' Yomiuri Shimbun, December 15, 2006.

43 Global Times, 16 December, 2010, available at <http://opinionglobaltimes.cn/ editorial/2010-12/602061.html accessed on 10 January, 2011.

44 Brahma Chellancy, 'Hindi Japani Bhai Bhai,' Times of India, New Delhi, 4September, 2014. 